\title{
脳幹部血管奇形の臨床症候について
}

\section{-3 症例の検討一}

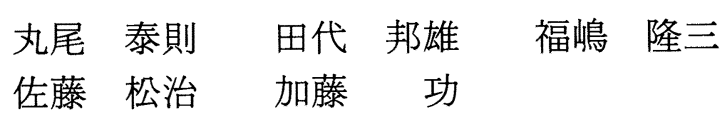

要旨：脳幹部血管奇形は稀な疾患で, その臨床症状は様々である. まったく無症状のまま経 過し, 剖検時に偶然に発見されるものから, 致死的な大出血を招こすものまである. 私達は脳 幹部血管奇形としては特異な臨床経過をもった 3 症例を経験したので報告する. 症例 1 は左動 眼神経麻痖と右片麻痺で発症し, Weber 症候群を呈した。CT スキャンと脳血管写より静脈性 血管腫と診断された。症例 2 および症例 3 は長期間にわたって, 種々の脳神経麻瘏, 錐体路症 状, 小脳症状が寛解増悪をくり返しながら進行し, 経過中多発性硬化症 (MS) との鑑別が困難 であった。いずれも神経放射線学的検査により脳幹部血管奇形と診断された。長期生存しその 臨床経過が MS に類似した脳幹部血管奇形の症例は, 私達の 2 例を含めて28例が報告されてい る，寛解増悪を示す脳幹症状を呈する症例の場合，頻度は少ないとは言光，脳血管奇形も疑っ て注意深い神経放射線学的検査を行なら必要がある。

Key words : brainstem vascular malformation, Weber's syndrome, multiple sclerosis, CT scan, angiography

(脳卒中 $9: 218-225,1987$ )

脳幹部血管奇形は稀な疾患であり，まったく無症状 のまま経過し，剖検のときに偶然に発見される場合か ら，致死的な大出血を打こすものまで，その臨床症状 は様々である ${ }^{11}$. 今回私達は脳幹部血管奇形としては 特異な臨床経過をとった 3 例を経験したので報告す る. 1 例は Weber 症候群を呈し, 2 例は脳幹症状が寛 解増悪をもって出現し臨床的に多発性硬化症 (MS) と 鑑別することが困難であった。

\section{症例}

症例 1.32歳, 男性

主訴：左眼䀫下垂，右上下肢脱力。

家族歴，既往歴：特記すべきことなし。

現病歴：昭和 59 年 3 月 14 日軽い頭痛, 悪心, 呕吐, が出現した。 3 月 16 日朝左眼䀫下垂に気づき, さらに 軽い右上下肢の脱力も出現した. 左眼䀫下垂は徐々に 増強し，3 日後には完全に下垂してしまった。 その後, これらの症状は徐々に改善してきたが, 精査のために

北海道大学脳神経外科神経内科部門
4 月 23 日当科へ入院となった.

入院時現症: 血圧 $128 \sim 62 \mathrm{mmHg}$, 脈拍 $68 /$ 分, 体温 $36.2^{\circ} \mathrm{C}$ であり, その他一般理学的所見に異常なし. 神 経学的現症では意識清明, 構音障害はない, 瞳孔不同 (右<左), 左対光反射減弱, 左眼䀫下垂, 左眼球の内 転上転制限を認め左動眼神経麻瘏と考兄られた。その 他の脳神経は正常であった。軽度右片麻疸, 右上下肢 にて腱反射方進を認めた。知覚異常, 小脳症状は認め なかった。

検査所見: 検尿, 血液一般, 電解質, 肝 - 腎機能, 心電図, 頭部単純写真に異常なし, 脳沗䯣液も正常で あった。頭部 CTスキャンにて左大脳脚から左視床部 にかけて輸状の高吸収值域を認め, 造影剂の投与によ り上記病変のうち左視床部がやや増強された（図 1 ). 椎骨動脈写動脈相にて, 後視床穿通動脈が側面像で前 万へ変位していた。晚期動脈相および静脈相では左視 床部に caput medusae 様の多数の小静脈を伴なう medullary vein が描出され太い導出静脈に注いでい た（図 2). 内頝動脈写では異常所見は認めなかった。 症例 $2: 58$ 歳, 女性. 

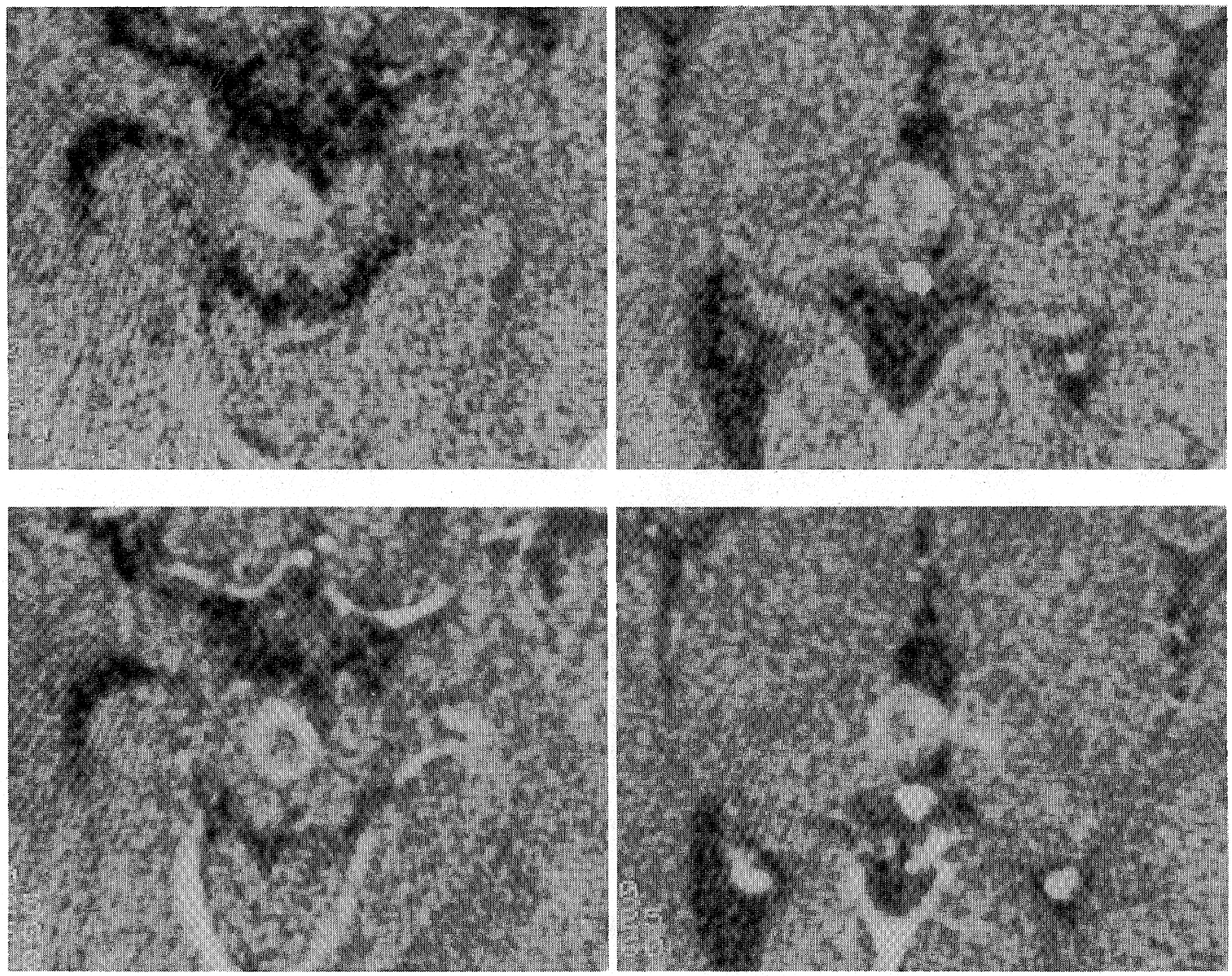

図 1 症例 1 の CT スキャン. 上段：単純 CT, 下段：造影 CT

主訴：舌のもつれ，複視，歩行障害.

家族歴，既往歴：特記すべさことなし。

現病歴：昭和54年より難聴と構音障害が出現し徐々 に増悪した。昭和 55 年に與下障害と軽い上下肢の脱力 を自覚するようになった。昭和 56 年 1 月の或る朝起き ると，全方向にて物が二重に見觉ることに気づいた． 同時に歩行時のららつも出現した。これらの症状は 2，3 日で㪕快したが完全に消失したわけではなかっ た。昭和56年 7 月 24 日朝ふらつきが強く，立つことが できなかった。㺞下障害も強くなった。ららつきは徐々 に倝快したが，つか亲り歩きがやっとであった，同年 10月20日近医に入院して経過をみていたが，11月15日 突然昏睡状態となり呼吸も停止した。直ちに気管切開 ののら人工呼吸器が装着された。意識は徐々回復し, 1 カ月後には清明となり人工呼吸器から離脱すること がでさた。しかし，四肢は完全麻瘏の状態であった。 昭和57年 5 月 18 日精查のため当科入入院となった。

入院時現症: 血压146 $80 \mathrm{mmHg}$, 脈拍 $62 /$ 分, 体温 $36.8^{\circ} \mathrm{C}$ であり，その他一般理学的所見に異常なし。神 経学的現症では意識は清明だが, 構音障害, 燕下障害, 強制泣・笑が見られ仮性球麻㽻の状態であった。上方 視にて上向きの眼振, 両側外転神経麻疩, 左末梢性顔 面神経麻疩, 両側聴力低下 (左>右) が見られた。そ の他の脳神経は正常であった，四肢麻疩（左>右）の 状態で, 左上下肢にて腱反射穴進, 両側 Babinski 拉上 びChaddock 反射陽性, 右半身飞て触痛覚低下，四肢 拉よび体幹に小脳性失調，口蓋ミオクローヌスが認め られた。下肢の脱力と小脳性失調のために歩行不能で あった。

検查所見：検尿, 血液一般, 電解質, 肝 - 腎機能, 心電図，頭部単純写に異常なし、脳传骨迹液も正常. 頭 部 CT スキャンにて，橋中央部に一部低吸収值域を含 む高吸収值域を認めた。この病変は造影郕により著明 に増強された。橋周囲の脳槽は開存して掞り橋腫脹の 所見はない(図 3). 椎骨動脈写動脈相では異常所見は 見られなかったが，静脈相にて橋背側に太い異常血管 

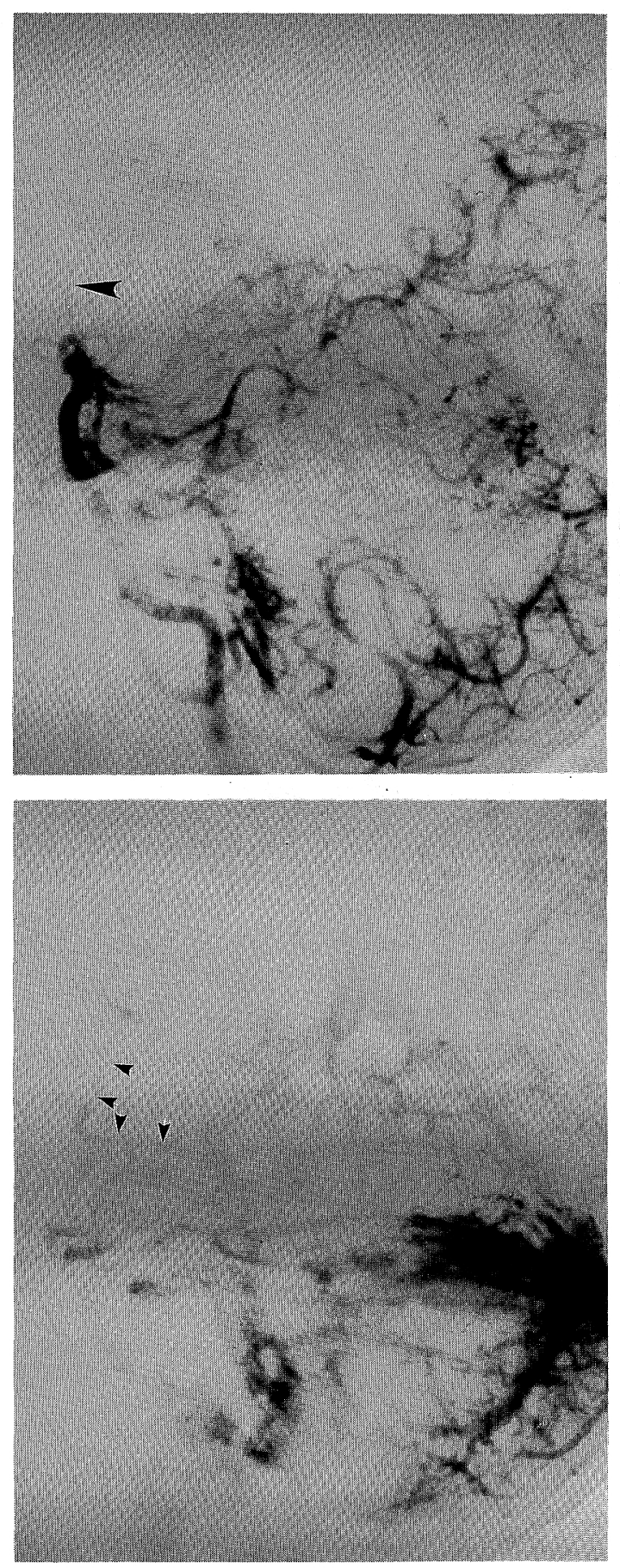

が描出され（図 4a)，ここへ細静脈が流入していた。左 下虫部静脈と左橋腕静脈が右に比して太く病変の導出 静脈之考兄られた（図 4b) 内䅡動脈写では異常所見な ᄂ.

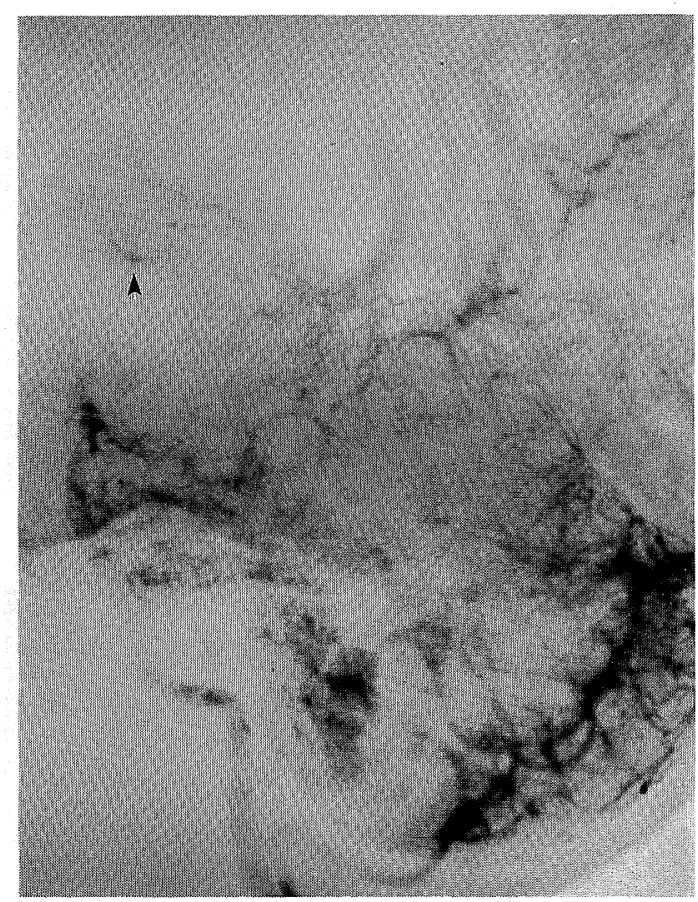

図 2 症例 1 の椎骨動脈写（側面像）
a. 動脈相
b. 動脈相 (晚期)
c. 静脈相

\begin{tabular}{l|l}
$\mathrm{a}$ & $\mathrm{b}$ \\
\hline $\mathrm{c}$ &
\end{tabular}

症例 $3: 53$ 歳, 女性.

主訴：舌のもつれ，歩行障害.

家族歴，既往歴：特記すべきことなし。

現病歴：昭和 53 年に自動車を運転中に道路上の 2 本 

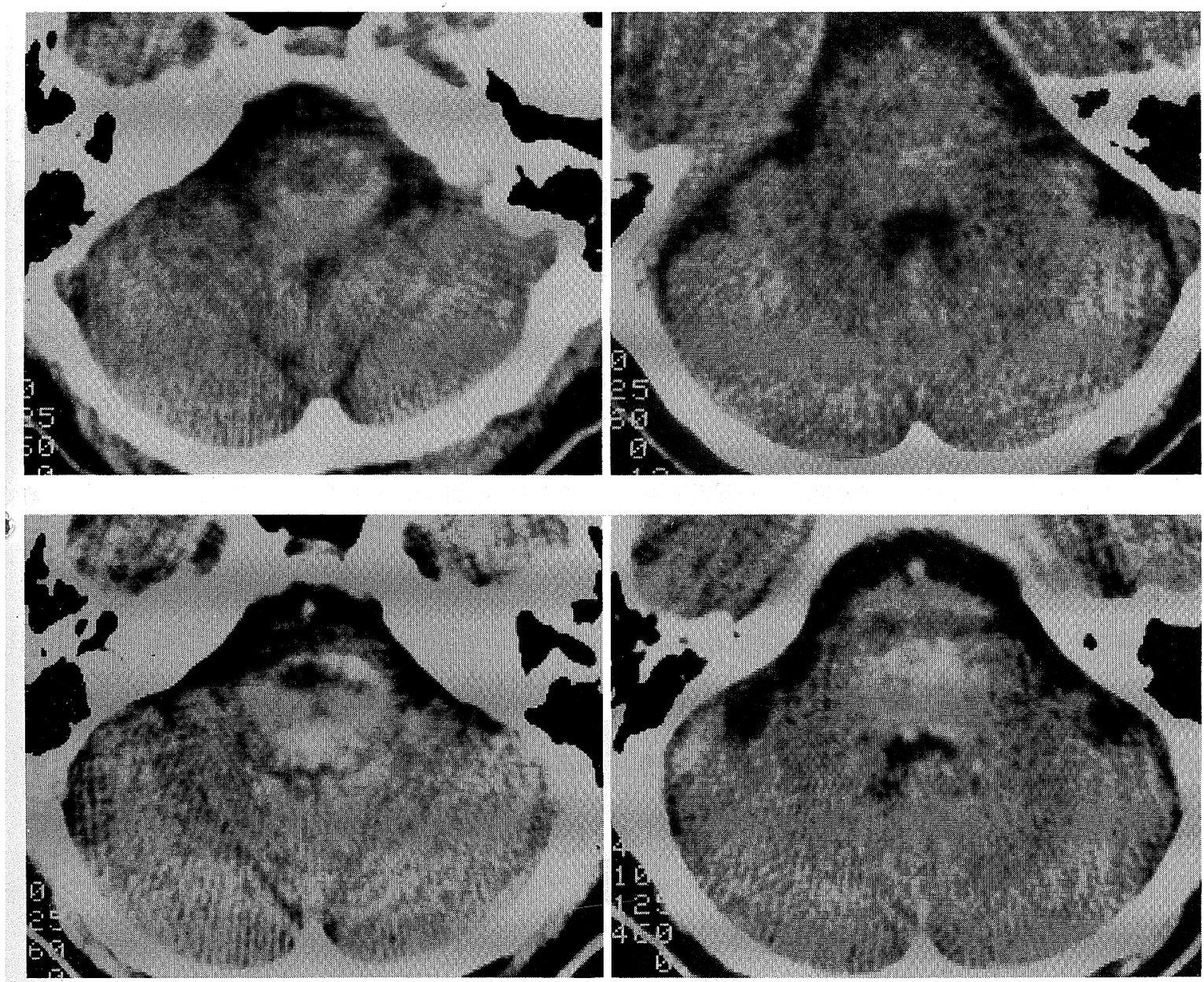

図 3 症例 2 の CT スキャン。 上段：単純 CT, 下段：造影 CT.
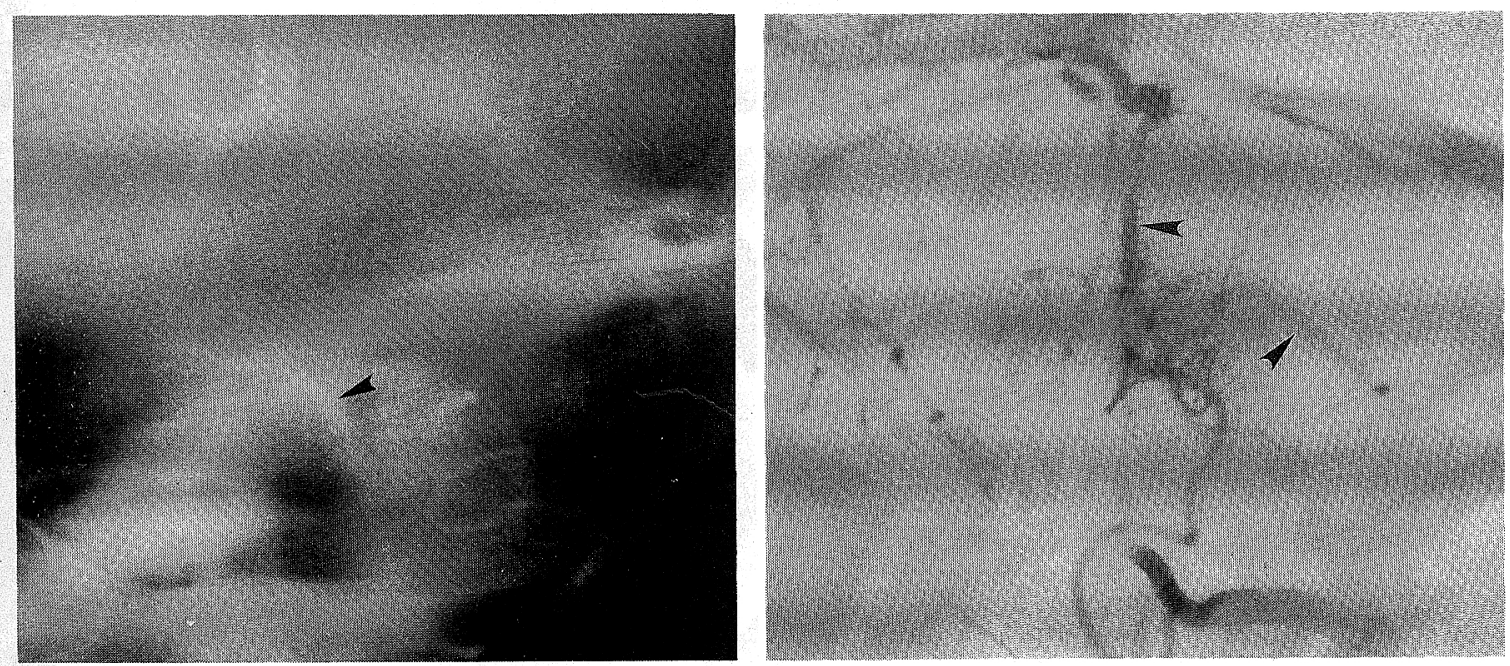

$\mathrm{b}$

図 4 症例 2 の椎骨動脈写 (静脈相)。a：側面像 (断層)， b : 正面像 
の平行な線が重なって見えたり，前方の 2 台の車が重 なって見兄るといらことがあったが，これは一時的な ものであった。昭和55年より歩行時のふらつき自覚 するよらになり，以後徐々に増悪した。ささらに左肩か ら左上肢にかケてのピリピリ感, 舌のもつれ, 嚥下障 害などがつぎつぎに出現した。この頃, 他院の神経内 科へ入院し MS と診断された。昭和59年 3 月 5 日起床 時に右顔面が麻瘦していることに気づいた。同年 8 月 27日精查のために当科入院となった。

入院時現症：血圧 $138 \sim 72 \mathrm{mmHg}$, 脈拍 $62 /$ 分，体温 $36.2^{\circ} \mathrm{C}$ であり, その他一般理学的所見には異常なし。 神経学的現症では意識は清明だが，構音障害が見られ た. 两側方視にて水平性眼振, 右三叉神経麻痖, 右末 梢性顔面神経麻痺, 右舌咽迷走神経麻痺, 両側舌下神 経麻瘦, 軽い左片麻疩, 左半身触覚痛覚低下, 口蓋 ミ オクローヌスを認めた。さらに四肢执よび体幹に著明 な小脳性失調を認め, このために歩行はまったく不能 であった。
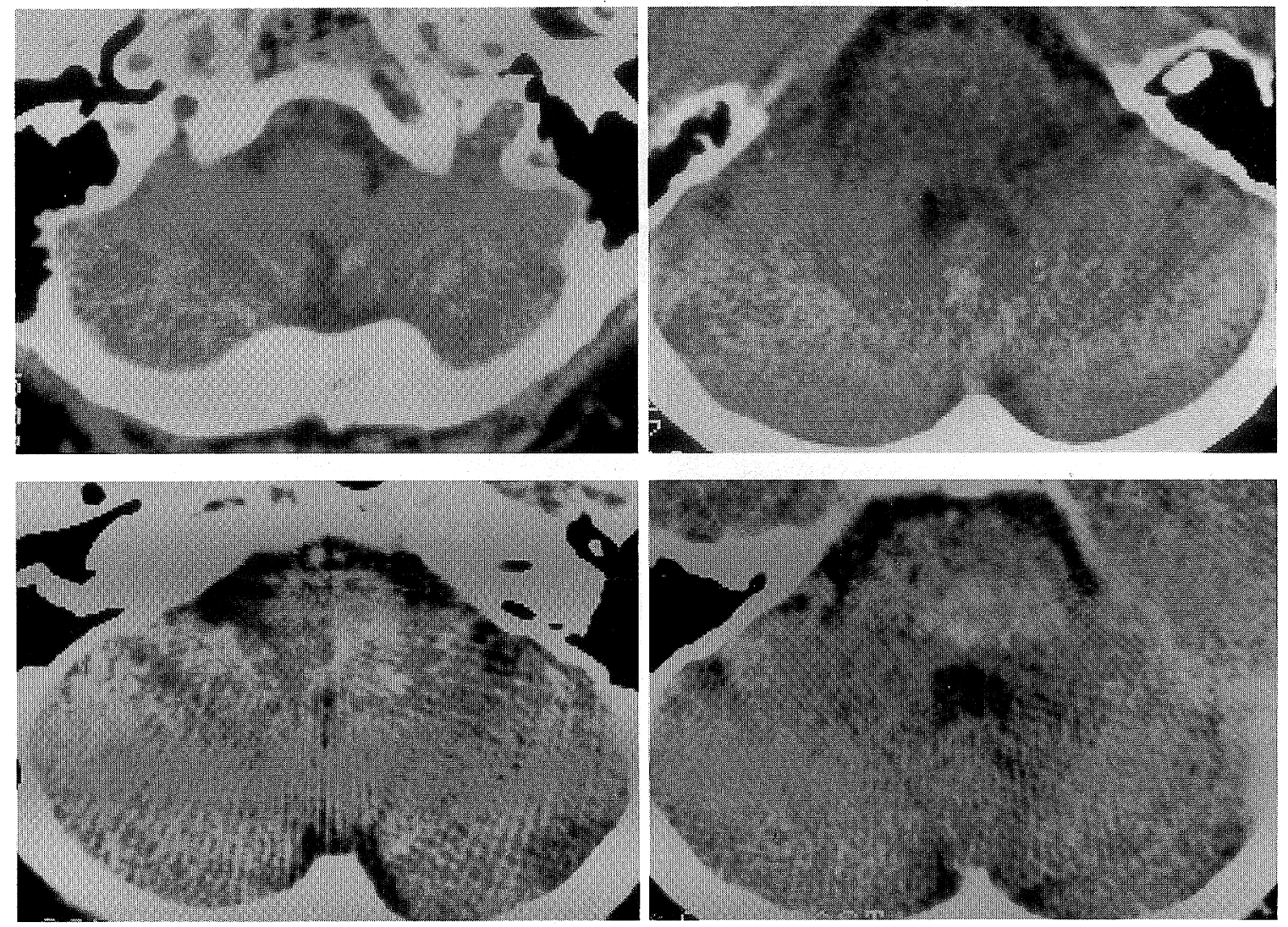

図 5 症例 3 の CT スキャン. 上段：単純 CT, 下段：造影 CT.
検查所見：検尿, 血液一般, 電解質, 肝 - 腎機能, 心電図, 頭部単純写に異常所見なし, 脳隹髄液も正常, 頭部 CT スキャンでは，単純 CTでは異常を認めな かった，造影 CT にて橋の中央部からゃや右寄りに高 吸収值域を認め，これは延䯣にまで及んでいたが， mass effect は無かった（図 5 ). 内頚動脈写，椎骨動 脈写ともに異常所見はなかった(図 6 )。な拉 6 力月後 に抏こなわれたCT スキャンでも，上記とまったく同 じ病変が認められた。

\section{考察}

近年, 神経放射線学的診断技術の進歩に伴ない，頭 部 CT スキャン，脳血管撮影の所見から，高率に脳血 管奇形が診断できるとする報告がふらてきている，前 原ら ${ }^{2)}$ は，神経放射線学的検查と神経症状を合わせて 総合的に判断することによって，82\%で正しい組織診 断に到達しらると述べている，静脈性血管腫の脳血管 撮影での特徵は静脈相において，放射状に配列した 

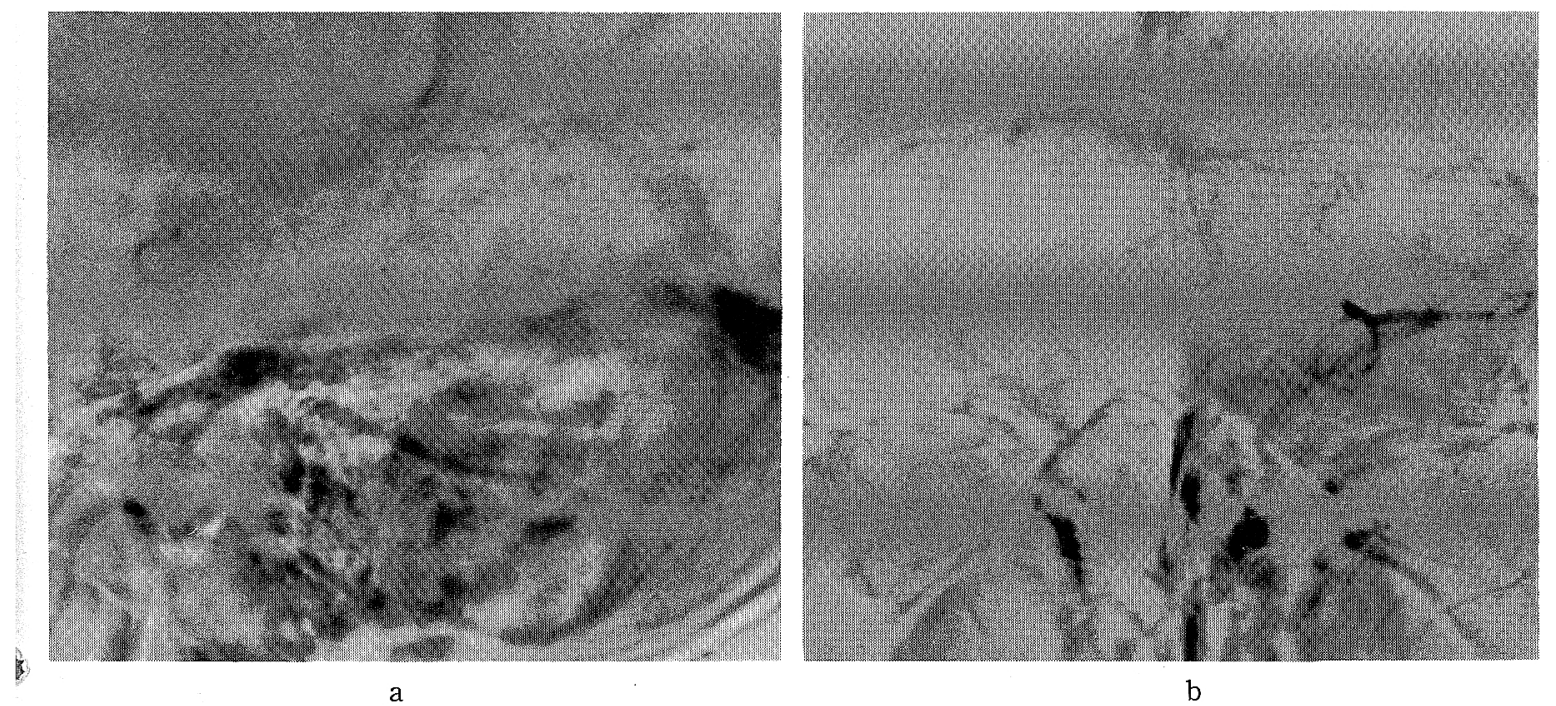

図 6 症例 3 の椎骨動脈写 (静脈相). A：側面像。 b：正面像

medullary veinが太い静脈幹に流入する所見であ る ${ }^{3)}$. CT スキャンでは高吸収値を示するの，等吸収值 を示するの様々であり，造影 CTでも線状に造影され るものや，結節状に造影されるものがあり一定しない が，何らかの異常を呈することが多くスクリーニング として有用であるとされている ${ }^{4}$. 症例 1 , 症例 2 はこ れらの所見とよく一致し，神経放射線学的に静脈性血 管腫と診断された。症例 3 では脳血管撮影と単純 CT で異常所見以得られず，造影 CT にて橋，延髄に高吸 収值域を認めた。この所見上り鑑別しなけ机ばならな いものとして, 脳幹部のグリオーム ${ }^{5)}$, 悪性リンパ腫 ${ }^{(1)}$, 脳幹脳炎》などがあげられるが，橋の腫脹があったく ないこと，6 カ月後のCT スキャンでもまったく同じ 所見を認めたこと，いずれの疾患にしても経過が長す ぎることより否定的である。李た，後に述べるように 臨床経過から MS との鑑別が問題になるが，MSで plaque が造影剂により増強されるのは急性期8である のに対して，症例 3 では症状の落ちついた時期に増強 効果が見られていることより, MSの plaque とは異な るものと考光られた，以上より症例 3 は長期間にわた り脳幹症状をくり返し, 造影 CTにて mass effect 持たない高吸収値域を認めるような，脳幹部血管奇形 が最も考点られる。

次に各症例の臨床経過について考光てみる。症例 1 は頭痛, 呕吐で発症し,ついで右動眼神経麻瘒と左片 麻㾇が出現し，Weber 症候群を呈した。 Weber 症候群 は大脳脚内側部を和かす種々の疾患で沶こるが，近年
CTスキャンの発達にともない生前にその病変を確認 できるようになっだ．本症例でも左大脳脚部に石灰 化と思方孔る輪状の高吸収值域を認め, これは脳血管 奇形の一部々考克られた。本症例は頭痛之呕叶で発症 していることより, 髄内への小出血が神経症状発現の 原因々考党られた。大井ら ${ }^{10)}$ は顔面の痛文で発症し，そ の後 6 年間にわたって左動眼神経麻疩と右片麻疸が宽 解と増悪をくり返した症例を報告した。CTスキャン にて左大脳脚に石灰化と思われる高吸収值域を, 椎骨 動脈写にて vascular stain を認めたため脳血管奇形と 診断している。彼らは神経症状が時間的多発性を示し たことは MS に類似するも，病変部位の空間的多発性 がないことより他疾患が考克られるとしている。

つぎに症例 2 ，症例 3 について考えてみる，症例 2 は55歳で発症し, 仮性球麻盘, 脳神経麻痺, 四肢の脱 力, 小脳性失調といった多彩な脎幹症状が寛解増悪を くり返しながら進行した。 6 年を経過した現在, 他院 にて療養中である。症例 3 は47歳で発症し, 症例 2 と 類似の経過をたどり，7年を経過した現在は自宅にて 療盖中である。両者とも多彩な神経症状が時間的多発 性をもって出現して打り，臨床経過だけから考光ると MS との鑑別は困難である.実際, 両者とも神経放射線 学的に脳血管奇形々診断されるまでは MS が最も疑 われていた、ただ $6 ， 7$ 年の経過中に脳幹以外の症状が なかったこと, 症例 2 では発症年龄が55歳と高齢で あったことはMS以外の疾患を考兄させる材料で あったかもしれない。 
Stahl $ら^{11}$ は発症から 1 年以上生存した脳幹部血管 奇形の 3 例を報告し, 文献例18例と合わせて21例を検 討している.彼らによるとすべての症例の臨床経過は, 脳神経麻疸, 錐体路症状, 小脳症状が寛解増悪をくり 返すという点で共通しており, MS の臨床経過と類似 している. 21例の中に telangiectasia が 6 例含まれて いるが，このような症例ではCT スキャン, 脳血管撮 影でも所見がなく生前診断は困難であるとしている。

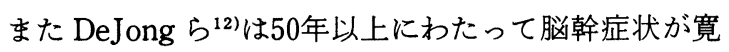
解増悪をくり返し, 剖検にて脳血管奇形を確認した症 例を報告した。Britt ら ${ }^{13)}$ は脳血管撮影にて所見がな く,20年間 MS と診断されていた症例に CT スキャン を施行したところ, 橋に高吸収值を認めたため手術を おこない, 動静脈奇形を確認した症例を報告した。そ の他 Delman ${ }^{14)}$, Sadeh ら ${ }^{15)}$ が同様の症例を報告して いる. 長期生存し, その臨床経過が MS と類似してい た脳幹部血管奇形の症例は, 私達の 2 例を加えると現 在までに 28 例が報告されている．脳血管奇形が神経症 状を発現する機序としては, 髄内への出血, 血管奇形 自体の増大による周囲への压迫, steal 現象による周囲 組織の虚血などが考えられるが，私達はこれまで述べ てきたような寛解増悪をくり返す神経症状の発現機序 は, 脳血管奇形からの小出血ではないかと考えている.

最後に, 寛解増悪を示す脳幹症状を呈する症例の場 合, 頻度は少ないとは言光, 脳血管奇形も疑って注意 深い神経放射線学的検査を㧍こなう必要があることを 強調したい。

\section{文献}

1) McCornick WF, Hardardman JM, Boulter TR: Vascular malformations ("Angiomas") of the brain, with special reference to those occurring in the posterior fossa. J Neurosurg 28: 241 $-251,1968$

2) 前原忠行, 田坂 晧：比較的稀な脳血管奇形の神 経放射線学的検討ーコンピューター断層撮影々脳 血管造影の比較検討一. 脳神経 $33: 1147-1155$, 1981

3) Fiersteien SB, Pribram HW, Hieshima G: Angiography and computed tomography in the evaluation of cerebral venous malformations. Neuroradiology $17: 137-148,1979$

4）太平貴之, 戸谷重雄, 奥井俊一ら：脳静脈性血管腫 のCT 所見. CT 研究 $6: 33-42,1984$

5) Sarkari NBS, Bickerstaff ER: Relapses and remissions in brainstem tumors. Br Med J 2: 21 $-23,1969$

6) Singh A, Strobos RJ, Singh BM, et al: Steroid-induced remissions in CNS lymphoma. Neurology(Ny) 32 : 1267-1271, 1982

7）丸尾泰則, 田代邦雄, 松本昭久ら：単純へルペスウ イルスによる脳幹脳炎の 1 例。臨床神経 11 ： 1168-1172, 1984

8) Barrett L, Drayer B, Shin C: High-resolusion computed tomography in multiple sclerosis. Ann Neurol $17: 33-38,1985$

9）田代邦雄, 森若文雄, 下山三夫ら：Weber 症候群 の CT 像. 神経内科 $12: 506-508,1980$

10）大井長和, 井村裕夫, 西谷 裕ら：血管奇形に上る と思われる単眼性 Double Elevator Paresis の 1 症例。眼科臨床医報 $73: 910-914,1979$

11) Stahl SM, Johnson KP, Malamud N: The clinical and pathological spectrum of brainstem vascular malformations. Long-term course simulates multiple screlosis. Arch Neurol $37: 25-29,1980$

12) DeJong RN, Hicks SP: Vascular malformation of the brainstem: Report of a case with long duration and fluctuating course. Neurology 30 : 995-997, 1980

13) Britt RH, Connor S, Enzmann DR: Occult arteriovenous malformation of the brains tem simulating multiple sclerosis. Neurology $(\mathrm{Ny})$ $31:$ 901-903, 1981

14) Delman M: Posterior fossa arteriovenous malformation. Am J Ophthalmol 56 : 409-413, 1963

15) Sadeh M, Shacked I, Rappaport ZH : Surgical extirpation of a venous angioma of the medulla oblongata simulating multiple sclerosis. Surg Neurol $17: 334-337,1982$ 


\title{
Abstract \\ Clinical manifestations of brainstem vascular malformation -Report of 3 cases-
}

\author{
Yasunori Maruo, M.D., Kunio Tashiro, M.D., Ryuzo Fukushima, M.D., \\ Shoji Sato, M.D. and Isao Kato, M.D.
}

Section of Neurology, Department of Neurosurgery, Hokkaido University School of Medicine

Three case of brainstem vascular malformation were reported. Case 1, 32 year-old man, presented with left-sided ptosis and mild right hemiparesis, was clinically diagnosed to have Weber's syndrome. Vertebral angiography showed medullary veins with a medusa like pattern and computed tomography (CT) demonstrated a ring-like high density in the left cerebral peduncle and left thalamus. This case was considered to have a venous angioma of the midbrain and the thalamus neuroradiologically. Case 2, 58 year-old woman, and case 3,53 year-old woman, were thought to have been multiple sclerosis (MS) at some time in their courses because of their progressive and intermittent clinical courses. Vertebral angiography of case 2 showed large draining veins in the dorsal aspect of the pons. CT scan demonstrated an enhansing round density area without a mass effect in the pons. The lesion was suggestive of a venous angioma. Vertebral angiography of case 3 showed no abnormal findings. However, CT scan showed an enhansing nodular density area in the right side of the pons and the medulla oblongata. The lesion was also suggestive to be a vascular malformation. The patients with the progressive and intermittent neurological signs and symptoms due to brainstem vascular malformation can be quite difficult to differentiate from other diseases such as MS, brainstem glioma or brainstem encephalitis. It is stressed that the patients with these kinds of clinical history should be carefully examined neurologically and neuroradiologically. 